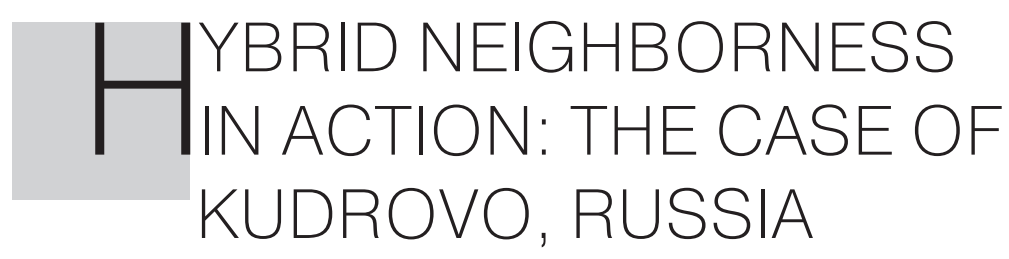

\title{
Olga Gromasheva
}

Olga Gromasheva, School of Social Sciences, Wageningen University (Netherlands). Address for correspondence: Rural Sociology group (Bode 50), P0 Box 8130, 6700 EW Wageningen, Netherlands. olga.gromasheva@gmail.com.

This article is based on the findings of the studies carried out by the author since 2017 in Kudrovo, Leningrad Oblast (Russia). The research was conducted within two collective projects: "New Urban Sharing Economy: P2P/Sharing and Digital Economy," funded by the Leontief Centre (Russia), and "The Layered Cake of Neighborness," funded by the Kone Foundation (Finland).

The article explores relationships among neighbors in the new housing developments of Kudrovo, a town bordering Saint Petersburg (Russia). Kudrovo is a vivid example of neighborness, a large part of which originates and happens online; however, it does not stay entirely on the internet but creates multiple offline activities and changes the materiality of the area. In Kudrovo I documented a large number of neighbors' initiatives that contributed to security, town improvements, alternative economy, local identity formation, as well as leisure, educational, and other activities. Inspired by actor-network theory, the analysis pays attention to human and nonhuman actors with a focus on the roles of residents and digital infrastructure in these interactions. It is not face-toface interaction or short geographic distance between people that allows them to reach the highest potential of neighborness but the connectivity to the body of "hybrid neighborness" - a digital-human network that functions $24 / 7$, unites thousands of local residents, keeps the history of all previous interactions, responds immediately, and can be easily appealed to in an incredible variety of situations from seeking moral support to helping with practicalities of life. Although this article presents some examples of particular networks and actors involved, and restrictions and strategies to bypass them, its main purpose is to show the features and potential of hybrid neighborness by demonstrating how it works in Kudrovo.

Keywords: Hybridization; Neighborness; New Housing Developments; Human and Nonhuman Actors; Digital Infrastructure; Practices of Sharing

\section{INTRODUCTION}

I was born, grew up, and lived most of my adulthood in the center of Saint Petersburg, Russia, in an apartment block that our family moved to right after it was erected in the late 1970s. We had very close relationships with a few neighbors, around whom I grew up. Leaving your keys with the neighbors, asking them to walk the dog, sharing food, borrowing money, and giving presents was common. Our interactions were faceto-face or by phone; we did not communicate on social networking sites (SNSs) even 
when this became a common practice. With new neighbors, who moved in over the last two decades, we barely greeted each other.

Six years ago I moved to Kudrovo in Leningrad Oblast (hereafter, LO), where high-rises were built in place of an abandoned sovkhoz. During the last decade, the population of Kudrovo has increased from several dozens to over 100,000, ${ }^{1}$ and in 2018 Kudrovo changed its official status from village to town. In Kudrovo I noticed different patterns of neighbors' interactions. In the elevator, people rarely say "hello" to each other; however, online conversations among neighbors are frequent, and these communications spills over into various offline activities. Surprisingly, soon after moving I found myself making pancakes for a picnic, helping to conduct a natural history quest, discussing Kudrovo development at an urbanism seminar-and I was doing all that with neighbors previously unknown to me, whom I met on the most popular Russian social network VKontakte (hereinafter, VK). Among hundreds of local Kudrovo pages on VK, "Kudrovo Life" (hereinafter, KL; "Zhizn' v Kudrovo" in the original Russian $)^{2}$ is one of the largest and the most vibrant. In the posts on KL participants call each other "neighbors," which is extraordinary for a page with over 71,000 subscribers ${ }^{3}$ scattered on a territory of around 400 hectares. ${ }^{4}$ Being intrigued by a new type of neighborness I sensed in Kudrovo, I started several research projects on neighbors' practices of sharing, the role of digital infrastructure in residents' interactions, and urban greening. The theoretical and methodological frameworks of the research were developed in close collaboration with Liubov Chernysheva and Elvira Gizatullina who conducted studies of similar design in Parnas, a large new district of Saint Petersburg. Although they documented less intense and varied activity in Parnas, in both cases we deal with the same phenomenon.

${ }^{1}$ By January 2021 Kudrovo had 49,079 officially registered residents. However, according to the estimations by local activists, in March 2018 already 70,000-90,000 people were de facto living in Kudrovo. When all housing construction is over by 2040, the town population will be over 200,000. See “Chislennost' naseleniia Rossiiskoi Federatsii po munitsipal'nym obrazovaniiam na 1 ianvaria 2021 goda," Federal'naia sluzhba gosudarstvennoi statistiki (Rosstat), July 30, 2021, https://rosstat.gov.ru/compendium/document/13282; “Dvizhenie aktivistov Kudrovo / Post / Chislennost' naseleniia Kudrovo," VK, March 28, 2018, https://vk.com/wall-137580405_13314; Iulia Gil'mshina, "Smirites', Kudrovo ne ostanovit'," 47 News, March 1, 2019, https://47news.ru/ articles/153032/.

2 On VK, open, closed, and private groups and public pages can be generated by individuals, teams, and organizations. Each of them has different combinations of options and restrictions (for more details see "Raznitsa mezhdu gruppoi i publichnoi stranitsei," VK Live: Vse o VK, January 20, 2018, https://vk.com/@live-club-vs-public). KL is a public page where content is visible to everyone but posts are published only after approval by the administrator.

3 “Zhizn' v Kudrovo" (https://vk.com/kudrovolife).

${ }^{4}$ In KL posts (but excluding comments) the word "neighbors" has been used several times more frequently than such common terms as "friends," "people," "residents," and "kudrovchane/ kudrovtsy" (inhabitants of Kudrovo). As the automatic built-in word search did not differentiate whether these words were used in salutations or posts' bodies, I read all posts for one week (260). Most posts contained no salutation or impersonal ones such as "everybody," "hi," or "good morning." But if a common term was used to define addressees, the salutation "neighbors" was used more than four times more frequently than other salutations. 


\section{THEORETICAL FRAMEWORK AND METHODOLOGY}

Large new developments on the city fringes, such as Kudrovo and Parnas, are often criticized by journalists and scholars for their spatial organization that facilitates atomization of residents, poor interactions among neighbors, lack of care for the neighborhood, and low quality of the living environment, all of which may potentially turn these territories into "ghetto" districts. Liubov Chernysheva (2019) demonstrated that, although new residential areas in Parnas suffer from insufficient transport and social infrastructure, cooperation among neighbors and initiatives aimed at the district's development are widely observable. She warns that labeling such districts as "ghettos" is not simply shortsightedness, because it does not take into account peculiarities of postsocialist cities and various social, political, and economic factors, but it is a dangerous misconception that stigmatizes the residents and has destructive performative power.

In both Kudrovo and Parnas our research team encountered a new type of relationships among neighbors. First of all, these relationships were always "in the making" - constantly shaping and reshaping, not fixed by permanent contacts of certain people and places, and inspired by the territory but not completely tied to it. Many conventional terms, such as, for example, "neighborhood," do not reflect all complexity and fluidity. Therefore, we use the concept of "neighborness" (sosedstvovanie) to emphasize the procedurality of this phenomenon, its creation through neighbors' interactions.

Secondly, the coexistence and interdependence of neighbors' online and offline interactions were of paramount significance. The hybridization of urban space has been documented by many scholars (de Souza e Silva 2006; Harris and Flouch 2010; Matei and Ball-Rokeach 2001; Miller and Slater 2000; Rheingold 2000; Zaporozhets and Lapina-Kratasyuk 2015). Analyzing neighbors' relationships in Kudrovo, we can talk about "hybrid neighborness"-online and offline practices are closely and inseparably intertwined, flowing in and out of each other and supporting one another. Hybrid neighborness also means that both human and nonhuman actors are involved and the role of digital technology is extremely important. The theoretical framework of hybrid neighborness is discussed elsewhere in this issue of Laboratorium (Chernysheva and Gizatullina 2021), so here I only briefly summarize its main features.

- Even though a large part of neighbors' interactions happens online, in the cozy virtuality of social media, these interactions are anchored in and built around the materiality of neighbors' living environment.

- The territory matters, and proximity is the key to being a neighbor, but at the same time the practices of hybrid neighborness are of exterritorial nature driven by the digital infrastructure. This nature of neighborness becomes possible by emphasizing not the physical presence at the moment but identification with the place: ${ }^{5}$ the neighbors' sense of belonging to this territory, their concern for

${ }^{5}$ Other studies (e.g., Grigorichev 2013) have documented a similar phenomenon. 
and interest in its life and development, and engagement in localized social networks. ${ }^{6}$

- Neighborhood watch and public spaces are also hybridized; online pages and chats often play the roles of benches and sidewalks: to exchange news and gossips, to shame and praise, to shape the rules of coresidence, and so on.

- The participants customize their interactions with neighbors on digital platforms according to their wishes: when, where, and what kind of neighbor they want to be in each particular case (they choose their own level of anonymity, involvement, frequency and types of engagement, and so on).

- It is not direct person-to-person connections but the connectivity of residents with the "body" of hybrid neighborness that is of top importance. Therefore, new neighborness is a work of maintaining this depersonalized digital-human network.

Online interactions of neighbors in new housing developments are extremely intensive due to many factors. Future homeowners take big risk by investing in the construction at the groundbreaking stage; this motivates them to monitor the developers and exchange information with their neighbors-to-be, and this is how hybrid neighborness starts: no apartment blocks have yet been erected, but they already found online people "living" on their floor. Then all together they go through the same stages-choose furniture, make repairs, resolve conflicts with developers. Another contributing factor is the homogeneity of residents: most of them are young, middle-class families or singles, ${ }^{7}$ and many of them migrated to Kudrovo from other Russian cities, ${ }^{8}$ which can also motivate them to build new networks to replace the lost ones.

${ }^{6}$ For example, thanks to a post on $\mathrm{KL}$, one Kudrovo resident found neighbors who helped to bring back a cell phone left behind in Protaras, Cyprus (all examples given in this article are real cases documented in online discussions, interviews, or observations).

7 This was how my informants characterized themselves and how they perceived other local residents. Such social homogeneity among residents of new developments, achieved due to the location and real-estate prices, generates a safer and more dependable environment for the neighborness (Brednikova and Zaporozhets 2016).

No official data is currently available about the age, gender, and other sociodemographic characteristics of the Kudrovo population. A street survey was conducted in two residential quarters of Kudrovo with a cluster random sample of 140 Kudrovo residents over 18 years old: 12 percent were pensioners, and the rest were divided between young and middle-aged people. The majority of respondents studied at university (79 percent), were currently employed (64 percent), were married ( 64 percent); more than a half had children under the age of $16 ; 33$ percent were men and 67 percent women; and 79 percent owned their Kudrovo apartments (Tykanova and Tenisheva 2020).

Among KL readers, 40 percent are men and 60 percent women; about 1 percent are under 18, around 12 percent over 45, and 87 percent are aged 18-45 ("Zhizn' v Kudrovo / Discussion Board / Topic 4 / Razmeshchenie reklamy," VK, January 5, 2017, https://vk.com/topic-51766355_34800382).

8 The quantitative analysis of KL subscribers demonstrated that among those who provided the information, less than a half indicated Saint Petersburg/Leningrad as their birthplace. Only one of my informants was born in Saint Petersburg, the other ten were born in other Russian cities or abroad, and most of them rented apartments in Saint Petersburg before becoming homeowners in Kudrovo. 
Due to its ever-increasing prevalence, some scholars have criticized digital communication for forcing out offline interactions, weakening social skills of face-toface interaction, causing addiction, anxiety, and so on. Other scholars, on the contrary, have emphasized the positive sides of online communication: increased access to information, new instruments to build solidarity and overcome loneliness, and so on. In particular, researchers have noted that digitalization in the suburbs increased communication and cooperation among neighbors and mobilization around local issues (Hampton and Wellman 2003; Voskresenskiy, Musabirov, and Alexandrov 2016).

Daniel Miller et al. (2016) argue that understanding online and offline relationships as mutually exclusive or opposed to each other is simplistic and warn against contrasting them as "real" (offline) and "virtual" (online) worlds. They perceive "relationships as created, developed and sustained through integrated online and offline interaction" (Miller et al. 2016:100). Although the authors think that this dichotomy may be misleading, they do not suggest abandoning these terms as they are widely used by the informants. However, their study demonstrates that in different cultural contexts even the meaning of these terms varies. ${ }^{9}$ In some contexts social media help to communicate with strangers and widen social networks, while in others to maintain relationships within families. Social media may help develop individualism or communality, absorb new practices or reconnect with traditions, conform or rebel. The focus should be on their functioning in a particular context under investigation. Miller et al. introduce the term "scalable sociality" (3) to demonstrate how people switch from Facebook to Twitter, from private messages to group chats, mixing texts, pictures, and audios to reach the desired type of sociality, appropriate for particular purposes.

Below I will demonstrate which social media are used in neighbors' interactions and how they contribute to the development of Kudrovo. Many of the discovered neighbors' initiatives may be analyzed within the framework of DIY urbanism that focuses on small-scale, bottom-up functional and esthetical modifications of the urban environment, although other approaches are developing too (Niederer and Priester 2016; Talen 2019; Volont 2019). Other initiatives by neighbors can be better understood through the prism of alternative economy, sharing economy, and collaborative consumption (Hamari, Sjöklint, and Ukkonen 2016; Kovács et al. 2017) with an emphasis on peer-to-peer-based activities to provide goods and services aimed to shorten the chain of transaction by bypassing intermediaries such as retail chains and agencies. Scholarship on activism, grassroots movements, local identity, and patriotism are also relevant. However, the aim of this article is not to put a certain label on each initiative but to look at them in their diversity.

Actor-network theory (ANT) helps to see these activities as interactions between human and nonhuman actors, in particular residents and localized digital infrastructure. Bruno Latour $(1992,2000)$ emphasized that social relationships cannot be studied without taking into account nonhumans who are not passive objects but

9 For example, in South India interactions on WhatsApp were perceived as an "offline" practice because of their more private character, while "online" was referred to public internet channels. 
actors in these interactions. ANT requires thorough examination of particular cases and of the role of each actor involved. The scope of this article does not allow for such comprehensive analysis, as in each particular case a different combination of actors was involved. The primary goal of this article is to map the variety of neighbors' initiatives within the hybrid neighborness. However, ANT is relevant for the data presented here, as examples will demonstrate, and it can be applied in a future analysis. I use ANT here as general inspiration, in an attempt to see how both residents and digital actors contribute to the production of this hybrid neighborness.

This article applies the framework of hybrid neighborness to the particular case of Kudrovo and enfleshes this theoretical skeleton by demonstrating the scope of neighbors' activities. In this article the activities of neighbors are called "initiatives," and only those produced by neighbors for other neighbors are included in the analysis, while others, organized, for example, by local authorities and developers, are not considered. I use the term "participants" instead of "subscribers" when referring to the social media users because one does not need to be a VK page subscriber to read and comment on posts, nor all KL subscribers are necessarily engaged in hybrid neighborness. ${ }^{10}$

The data for this article was collected from online discussions (Kudrovo VK pages, chats in WhatsApp and Telegram), ${ }^{11}$ in-depth interviews with Kudrovo residents, ${ }^{12}$ and participant observation. All materials were collected and analyzed by the author.

\section{IN CASE OF EMERGENCY, CALL ... YOUR NEIGHBOR? THE STORY OF ONE FIRE}

In February 2019 yet another fire started in one of Kudrovo apartment blocks. The fire department was called immediately, but the fire engines took 30 minutes to arrive, which is significantly longer than the statutory reaction time. Fire trucks had to come from the neighboring district, they could not use two entrances to the town because of height restrictors, and they were stuck in a traffic jam at the third entrance. The fire was put out 75 minutes after the phone call. No one died, but five inhabitants were evacuated by firefighters, and twenty residents were left without a home. According to preliminary information, electrical wiring caused the fire.

10 Among KL readers, 61 percent were subscribed and 39 percent were not (“Zhizn' v Kudrovo / Discussion Board / Topic 4 / Razmeshchenie reklamy," VK, January 5, 2017, https://vk.com/ topic-51766355_34800382).

${ }^{11}$ First, I uploaded all KL posts published during the first week of June 2017 (63,628 characters), coded them in NVivo, and compiled a glossary of the relevant keywords. Then I searched all $\mathrm{KL}$ posts and comments using these keywords.

${ }^{12}$ In 2018 I interviewed 11 organizers and participants of sharing initiatives in Kudrovo, who were recruited on $\mathrm{KL}$ or found through my personal network using snowball sampling. All informants were engaged in the KL discussions and communications with neighbors on other digital channels. Nine interviews were conducted face-to-face and two by phone. All informants had been living in Kudrovo for over one year. 
Immediately after the fire started, a post ${ }^{13}$ was published on $\mathrm{KL}$ with information and visuals, and all participants could broadcast and track the event online. This accident showed the incredible cooperation of neighbors. During the fire one resident took his infant children out of their burning apartment, and when he was coming back to rescue their cats, he found a neighbor lying on the staircase. While he was saving her, the cats died in the fire. Due to the lack of parking spaces in Kudrovo, all sidewalks were filled with cars, preventing the fire trucks from approaching the building. Neighbors had to move a dozen of cars from the sidewalks with their bare hands.

In the next few days, about 1,500 people donated a total of 500,000 rubles. The crowdfunding was organized by the KL administrator through a donation button. ${ }^{14}$ The money was distributed to the owners of three apartments destroyed by the fire. ${ }^{15}$ A place to bring clothes and necessities for the victims of the fire was announced in a KL post, but soon the collection was stopped because people brought too much stuff. Hundreds of people offered to give various things, from household appliances to doors, and invited the victims to come over for tea and support. Dozens of residents invited the victims to stay in their apartments for free. The KL administrator and several activists were managing these offers of help. The KL participants made sure that, while the main support went to the residents of apartments destroyed by fire, the owners of the apartments flooded during fire rescue also received help. Here is a fragment from a KL post published five months after the fire:

A post of gratitude. Hello, dear neighbors and wonderful people of Kudrovo! We are your neighbors from the apartment block where the fire happened this winter (the apartment flooded as a result of the firefighting). I did not get around to write to you about my appreciation and gratefulness for your support and help provided to us during that hard and stressful period. But today, when I see how you, the whole town, help a cat with kittens, my heart overfills with love to you and with a feeling that you all together are the power and might, and that I am happy to live with you and to do good.... Awesome, kind, warm-hearted neighbors, thank you for being here for me; it is worth a lot.

In this post the author also mentioned a number of people who helped her family in various ways during and after the fire: the KL administrator for information support; a man for taking her with the baby during the fire into his car; a woman for cleaning the apartment after the fire; another woman for providing an apartment to live for free; several men for transferring her stuff from the flooded apartment; two women and a man for "foster care" of her fishbowl, houseplants, and books; another

${ }^{13}$ The links to the original posts are not included here to preserve the participants' anonymity.

${ }^{14}$ The introduction of a one-click donation button on KL allowed participants to donate money not only faster but also safer (transfers through the button were controlled by the KL administrator, whom they trusted, while the accounts posted in comments often turned out to be fraudulent).

15 For comparison, the district administration promised to provide 20,000 rubles per family, and local administration 10,000 rubles per person. 
man for paying her transport costs to do the paperwork; yet another man for replacing doors and curtain track free of charge; and many other people for providing essentials, baby toys, financial help, and emotional support. This case was a vivid example of both the heroism of the locals and the failure of public services (although first residents moved into Kudrovo's new housing developments in 2011, the first fire safety station was opened only in October 2019, eight months after this fire). The analysis of online discussions demonstrates that in this fire many human and nonhuman actors were involved, some of them helped to fight the fire and support the victims (e.g., firefighters, fire trucks, KL, neighbors), while others obstructed the efforts (height restrictors, narrow passages, improperly parked cars, etc.).

This fire was a highly visible event: just the initial post on $\mathrm{KL}$ generated over 81,000 hits and 1,345 comments. Nevertheless, not every fire in Kudrovo "made such a career." In the fire of 2016, a fire truck also arrived 30 minutes after the phone call. By then, the fire was already put out with a fire extinguisher by neighbors and migrant construction workers. The fire started in the middle of the night, and the post about it was published on KL only after the fire was stopped. The online discussion was built not around supporting the victims but around blaming the guilty parties (car owners, authorities, developers) and, most of all, the victims, who were drinking and having a loud party in the apartment where the fire started. Different combinations of actors and conditions in one case (defective electrical wiring, "decent" families as victims, evening, real-time $K L$ post, engagement of the $K L$ administrator, etc.) compared to the other (party, drunk victims, night, post-factum KL post, fire extinguisher, etc.) generated two different types of interaction and support networks.

\section{REASSEMBLING THE NEIGHBORNESS}

In this part of the article I present examples of neighbors' initiatives ${ }^{16}$ and classify them according to whether they contribute to increasing security; developing the town (by doing-it-yourself or by forcing the authorities to fix the problems); getting goods and services outside of the mainstream channels; socializing with neighbors; or building local identity.

This article does not intend to cover all Kudrovo initiatives; however, it gives a condensed overview of activities documented by my research. Some initiatives fall into several categories identified above. In some cases, the initiative started purely as DIY but then was transformed by involving the authorities or the other way around. Furthermore, the informants were usually engaged in initiatives of several different types. This classification does not mean that the activity's aim (for example, to construct local identity) was the main and only purpose of all participants, and it is used here mainly to present the vast and complex data in a more digestible way. Moreover,

${ }^{16}$ See also the art-science exhibition If Your Iron Has Broken... (Saint Petersburg, Russia, April 19-May 14, 2019), https://privetsosed.org/exhibit-broken-iron. 
neighbors' goals and visions of the town's development and their practices of care for the territory are sometimes in conflict. ${ }^{17}$

\section{SAFETY NET}

New buildings with many uninhabited apartments are often objects of burglary. One example of hybrid neighborness in action is how participants protect themselves from unwelcome events like burglaries. Neighbors warn each other about strangers ringing the doorbells, as well as about changes in the material environment of the communal space. According to KL posts, burglars often apartment doors to inform their accomplices about accessibility of the apartment. Therefore, residents wipe off these signs from the doors and remove advertising flyers from their neighbors' doorknobs, because accumulated leaflets indicate that an apartment is unattended and, therefore, is an easy target for burglars.

Even though these actions mainly happen offline, most residents learn online about these risks and strategies to manage them. Both their awareness and practices of care are shaped by what they read online. KL makes them learn new words, such as zakladka (a stash of drugs), and develop similar outlooks: for example, suspect any expanded floor molding or displaced suspended ceiling in common areas to be a hiding place for drugs.

Carpooling is another example of safety-focused initiatives. After a bomb was set off in the Saint Petersburg metro by a terrorist on April 3, 2017, many people were scared to use public transportation. On KL dozens of people offered rides to their neighbors, and the KL administrator created a topic thread "Fellow Passengers" for drivers and passengers to find each other, which is still in demand.

This fragment from a KL post demonstrates how hybrid neighborness worked for one resident's safety:

I want to thank my neighbors and especially Ivan ${ }^{18}$ for saving me from a drug user who was breaking into my apartment at two o'clock in the morning. His [Ivan's] creation—safety chat in WhatsApp—works! I woke up at 2 a.m. when somebody tried to open my apartment door with his keys. Then he started to break the door. I immediately posted in our WhatsApp chat. In a few minutes, I heard that Ivan was talking to someone in our common corridor. I opened the door and was shocked: the floor was covered in blood, [and] Ivan was talking to a young guy with glassy eyes. Ivan took him away. Then from the chat I learned that this drug user was renting an apartment in our building; his apartment was located exactly as mine but three floors below. Probably he got to the wrong floor and tried to go home.... It turned out that the drug user broke the glass door of a common balcony - that is why there was blood on all floors. The neighbors called the police and ambulance. They arrived at 6 a.m. and took this unruly neighbor.... If you don't have a [WhatsApp] chat [among people living in] your pod'ezd [part of the building], create it! The police arrived only in four hours. I

${ }^{17}$ For analysis of such discrepancies in the identification of common resources and ways of their management, see Chernysheva 2020.

${ }_{18}$ The name was changed. 
don't know how I would have survived this horrible night if it was not for our chat and wonderful neighbors who are ready to come to the rescue at any moment!

Informant INT03 ${ }^{19}$ told another story: the car of a driver who hit a woman in Kudrovo was identified and located thanks to photos posted on KL. "It was not the police who found it," the informant emphasized. In these cases, Kudrovo social media worked as online police when official law enforcement bodies were idle. Hybrid neighborness also functions as a reputation network that may prevent crime:

In Kudrovo, I think, we have such a consolidated community [obshestvennost'], at least on the internet, much more than in other districts ... that feels responsible for what is happening here. I think that people here are more afraid to commit an offense. At least, those who live here permanently and know how things work here.... I thought that here in Kudrovo you could also very easily destroy your reputation. Because if you do anything bad, most likely people will learn about it. (INT03)

\section{DIY NEIGHBORNESS}

Kudrovo faces the problems typical of most new districts where apartment blocks were built faster than transport and social infrastructure. Popular KL hashtags (\#townwithoutpolice, \#townwithoutroads, \#townwithouthospital, \#townwithoutpublicspaces, \#townwithmanyzeros) attest to this. ${ }^{20}$ Multiple initiatives in Kudrovo were aimed at making the area more comfortable: cleaning up lawns, planting flowers, digging out the poisonous Sosnowsky's hogweed.

I regularly wash our [building's] lobby with a hose to get rid of dog piss, smokers' spit, and spilled beer. And the entrance to our building looks SO MUCH better than the neighboring buildings that do not have such a fool like me. If the managing company does not do it, it is not a reason to live in a pigsty. (comment on a KL post)

Kudrovo residents use $\mathrm{KL}$ to invite their neighbors to join ecological activities, such as plogging, for example, which combines jogging and picking up the garbage. Informants INT06 and INT10 reported that a VK page was created for another initia-

19 See the list of interviewees in the end of the article for more details about each of them.

${ }^{20}$ According to the law, social infrastructure should be developed only for the number of residents registered in Kudrovo. However, many residents keep their previous registration (propis$k a$ ) in Saint Petersburg: in their opinion, Saint Petersburg is closer to Kudrovo than the administrative center (Vsevolozhsk), and the quality of social, medical, and other services in Saint Petersburg is better than in Vsevolozhsk. While some public services lag behind the requirements even for the level of the registered population, the number of people actually living in Kudrovo is two-three times higher than the number of officially registered residents. Another frequent problem in Kudrovo is the transfer of responsibilities for services: for example, a developer terminates the maintenance of streetlights, but the local administration does not take over. 
tive that combines carpooling, recycling, and planting: activists collect plastic bottles and paper from residents and exchange them for seedlings that they plant together in Kudrovo.

The KL participants have initiated numerous charity events: visited residents of a retirement home, donated blood, brought presents to a local orphanage for children with special needs, made pancakes for homeless people. ${ }^{21}$ After a post on KL about too modest presents that the local administration prepared for the World War II veterans, participants suggested a fundraiser. It was organized by the KL administrator, and 40 veterans received presents from Kudrovo residents to celebrate the anniversary of the end of the Siege of Leningrad. Many KL posts are devoted to stray pets: Kudrovo residents have arranged temporary stays for them, organized fundraisers for surgery and photo sessions to help them find new homes, as well as delivered food, toys, and supplies to animal shelters.

When public agencies and managing companies fail to provide proper services in a timely fashion, Kudrovo activists take matters into their own hands. For example, dissatisfied with the quality of road repair by the municipal services (the supposedly fixed potholes reappeared in a few days), activists of Kudrovo and the neighboring Nevskii district organized an online fundraiser, found the required equipment, and repaired these potholes overnight without authorities' permission.

Many initiatives are one-time events, but when their leaders are ready to regularly invest time, initiatives can be shaped into informal networks with online channels. For example, the Foundation for Neighborhood Development (Fond sosedskogo blagoustroistva, FSB) was launched in 2019; it has a VK page and a Telegram channel. Over two years, through crowdfunding the activists collected over 370,000 rubles that were spent on planting trees, removing advertising stickers from street poles, and painting over advertising for brothels on sidewalks. On the FSB page on VK not only announcements and photos are published but also financial reports, which document how donations are spent on mulch, tools, paint, and so on. Upon provision of receipts, FSB can compensate Kudrovo residents for their expenses on cleanups, greening, and beautification of the territory. FSB also aims for systematic solutions: it pressures local businesses not to put advertising stickers on street poles and searches for a chemical solution that prevents leaflets from sticking the poles, as well as recruits volunteers for regular upkeep of planted trees. Therefore, the VK page allows FSB not only to crowdfund the money but also to crowdsource ideas, conduct polls, and find allies.

\section{BOTTOM-UP PRESSURE ON THE AUTHORITIES}

The previous section may give the impression that public authorities in Kudrovo are replaced by neighbors' networks. Sometimes, indeed, residents take snow shovels in their hands to clean the streets. However, most of their efforts are aimed at making the system work. For example, a KL post collected over 100 complaints from residents injured on ice-covered pavements, including a woman who suffered an open fracture

${ }^{21}$ Some initiatives originated in Kudrovo, while on others the residents collaborated with NGOs from Saint Petersburg. 
when she had fallen on ice and had to wait for medical assistance for over an hour (as you already know, Kudrovo is a \#townwithoutambulance). Activists used this data to put pressure on the authorities. ${ }^{22}$ One of the complications is that many roads and sidewalks in Kudrovo are in private ownership. In January 2019 a Kudrovo resident posted on the Instagram account of the LO Governor Aleksandr Drozdenko about people who were injured because of poor cleaning of the streets and proposed several solutions, in particular, legislative amendments to the LO Administrative Code to introduce hefty fines for owners who do not clean their roads in a timely manner. The governor immediately replied that additional snow-clearing vehicles would be sent to Kudrovo. Later this activist announced on $\mathrm{KL}$ that her proposed amendments were introduced and passed, the law was signed by the governor in March 2019, and, as the LO government website stated, the substantial size of the newly established fines was due to the high social significance of this problem.

Kudrovo residents regularly collect signatures on petitions and participate in public hearings. They post templates of letters that can be sent electronically to the procurator's office in a minute and help their neighbors to fill out the complaint forms. In December 2018 they organized an officially authorized picket demanding that local authorities and developers stop new construction in the town and build infrastructure instead. ${ }^{23}$

They also use such creative methods as flash mobs to draw attention to the problems or photo walks to map the undermaintained areas. Social satire is another way to address the problems: $\mathrm{KL}$ is replete with poems about local pressing issues, GIFs, and caricatures of officials created by residents. One KL participant has posted a humorous appeal to help public utilities in clearing the snow and a photo report of his own solution to the problem: whenever he takes out the garbage bin, he fills the empty bin with snow and melts it in his shower. The commentators called his method "the ice bucket challenge Kudrovo style."

In February 2019, in the local park the residents built snowmen who represented Kudrovo's hottest issues (snegoviki-problemoviki); among them were artworks titled We Need Roads!, Snow Policeman, Kudrovo Awaiter (Kudrovskii zhdun), and Duped Kudrovo Resident (Okolpachennyi kudrovchanin). The KL participants voted for best artworks, and the creators of three top-ranked pieces received prizes provided by the KL administrator.

DIY initiatives and efforts to influence the authorities are conducted in varied ways: by individuals, small groups, or temporary alliances of different groups. The largest and most famous coalition is the informal Movement of Kudrovo Activists (Dvizhenie aktivistov Kudrovo, DA), which was launched in January 2017. Their VK page has over 8,000 subscribers; they also use Instagram, Facebook, and Yandex.Zen. The reports on letters sent by DA activists to officials are published on Google Docs

22 "Polomannoe Kudrovo: Gololed otpravil zhitelei k vracham i v prokuraturu," Moika 78, January 30, 2019, https://moika78.ru/news/2019-01-30/184230-polomannoe-kudrovo-gololed -otpravil-zhitelej-k-vracham-i-prokuraturu/.

23 “Piket v Kudrovo za infrastrukturu. Park Okkervil' 2018," Kudrovo 24, uploaded December 24, 2018, video, 4:51, https://youtu.be/04V70M7myzY. 
with reference numbers, decisions taken, and texts of letters (in 2017 alone around 100 letters were sent to the authorities). DA activists work on most of the hot topics including lack of health care, fire safety, kindergartens, public transport, and bicycle infrastructure. DA launched or pushed forward the following initiatives:

- new bus routes with low-floor vehicles for people with limited mobility; road repairs; traffic signs, crosswalks, and public transport stops;

- construction of footbridge, new sidewalks, and ramps for baby strollers;

- removal of illegal retail pavilions;

- establishment of voluntary people's patrol and a local police office;

- removal of construction waste, introduction of wheel-washing facilities at construction sites' exits;

- installation of new benches, garbage bins, and street lighting;

- planting of hundreds of trees and bushes.

DA activists participate in the LO Town-Planning Council where they propose amendments to the local development master plan. They have joined the Supervisory Council for New Developments created by the LO governor. Together with landscape architects, Kudrovo residents, and officials, DA activists have prepared the concept and designs for a park development, a project that won the regional competition Constructing Comfortable Urban Environment and received 13 million rubles from the federal, LO, and local budgets.

The DA leader rejected several positions with the LO public agencies but accepted a job at a municipal institution because she wanted to put her efforts specifically into Kudrovo's development. In September 2019 she ran in the municipal elections but lost. DA and its leader have received both enormous support and sharp criticism (especially for building constructive dialog with authorities instead of having an open confrontation with them). In opposition to DA, an alternative network, the Team of Residents, was established before the 2019 election. It also aims to develop the town, as well as defend the residents' interests in courts. In the opinion of $\mathrm{KL}$ participants, it was not only falsifications during the elections but also conflicts between the Team of Residents and DA that prevented activists of both coalitions from being elected local deputies.

It is not unusual that such urban initiatives lead to wider political activism (Zhelnina and Tykanova 2019); however, the majority of initiatives documented in my study were primarily oriented towards very local and practical purposes, tried to avoid manifestations of political positions, and aimed to unify various people around the town-centered issues.

\section{THE ALTERNATIVE ECONOMY OF KUDROVO}

I use the term "alternative economy" to describe the ways to get certain goods or services outside of the mainstream channels. These activities may happen within the "gray economy" (i.e., without paying taxes), as well as to be fully legal but exist in parallel with the formal economy.

Probably most frequently neighbors' interactions occur around sharing-first of all, sharing of material objects. In Kudrovo sharing in multiple meanings of the word 
is popular. In the first sense, a person gives away something they do not need; therefore, the thing changes the person it lives with-it is transferred. The second type of sharing, lending, is when a thing is given to another person for a certain period of time and is later returned. The third type, shared use, implies that there is no physical transfer or that the giver still can fully or partially use what they are sharing-their car, skills, or equipment.

Although there are many digital platforms for exchanges (Darudar, Avito), sharing in localized SNSs is extremely popular due to geographical proximity and a large number of daily online visitors. Kudrovo residents clear the space in their apartments by giving away clothes, baby stuff, furniture, food, games, car accessories, tools, electronics, coupons, plants, and so on.

In most cases, things borrowed online were safely returned to the givers, but there have been several incidents when it did not happen. A young woman who threw away a borrowed mattress was mocked on $\mathrm{KL}$ and became the object of caricatures.

If transferred or loaned, the shared things might be given for free, for money, for collateral, or for the local "currency" called vkusniashka (yummy). Vkusniashka historically meant sweets, but now includes any food product from apples to chicken fillet. This exchange of things for food is so popular that KL participants have jokingly proposed to build a monument to vkusniashka in Kudrovo.

Although many posts on sharing were, and still are, published on $\mathrm{KL}$, the satellite VK page "Kudrovo Market"24 with over 26,000 subscribers was created specifically for this purpose by the same team of administrators. Here I give one example of how this digital platform shapes the neighbors' interactions and how they get around some of its restrictions. According to the page's rules, announcements about things given away for free or for vkusniashka can be posted directly on the page's "wall" (in which case they automatically appear in the subscribers' newsfeed), while things offered for money can only be published in photo albums (which prospective buyers need to open intentionally). Aiming to get their posts on the wall, participants publish very detailed descriptions of the foods they are seeking in exchange for whatever they are giving away: rompers for frozen cordon bleu from a certain store, or a new swimsuit for three jars of capelin caviar. Such cases mean that a relative price is more clearly defined and the vkusniashka is not, say, a chocolate bar sitting on the kitchen shelf but something that requires intentional shopping. Furthermore, as my informants told me, in personal messages between the exchanging parties vkusniashka is often substituted with money. This way the formal rules of publication are respected, but the terms of exchange are changed in private communication.

Most sharing interactions are one-time or short-term occurrences; however, some are ongoing. For example, informant INT09 has organized a bookcrossing shelf for neighbors at a local cafe. Some residents have also arranged collective purchasing of clothes, dishware, and other goods at wholesale prices or regular deliveries of milk products from a farm.

${ }^{24}$ https://vk.com/kudrovomarket. 
The KL page is full of examples of how Kudrovo residents help their neighbors: they pick up medication from the pharmacy, take care of a pet during holiday, and so on. Informant INT04 said that several years ago when there were no schools in Kudrovo, a neighbor had been driving her child to their school in Saint Petersburg for months together with her own children.

The KL administrators created other satellite VK pages: "Kudrovo Service" (manicure, massage, dog grooming), "Kudrovo Realty," "Kudrovo Jobs," "Kudrovo Dating," "Auto Kudrovo," "Zoo Kudrovo," "Kudrovo Gamers," among others. The KL team also uses Facebook, Instagram, Telegram, Twitter, YouTube, and the news portal Kudrovolife.ru. Only posts from individuals are published for free; companies pay for advertising, and advertising spots sell quickly. Therefore, $\mathrm{KL}$ and its satellites have become successful income generators for their administrators.

Another sharing initiative was a networking event organized by one of my informants, INT02. It included an exchange of business cards, speed-dating, exercising together, and a concert. Participation was free, and the event was run by volunteers who included a DJ and a quadcopter operator. Guests and volunteers were recruited on $\mathrm{KL}$, where photos of the event were published afterwards. The informant explained that she felt restless because so many professionals live in Kudrovo, but nobody knows "who is who":

I had this idea to understand who lives here, who is doing what, and can be useful for each other. Because, firstly, it is the easiest way to meet, then it is the easiest way to solve your problems in the search for someone, and it is also the easiest way to make money.... Here, those who wanted to know who their neighbors were, they would just come and meet everyone, and, so to say, everyone would compile their own database.... It was about the concentration of town residents.... I wanted to create an information field.... It allowed me in one day to meet personally, I don't know, 70 people, to learn what they are doing, how they look, get their contacts directly. In three hours.... I myself did not have any particular need to find anyone or anything.... I mostly did it not for myself. For me, it was more like a bonus - to get all these contacts and gain experience in event organization.

Thanks to this networking, she found like-minded neighbors to practice sports with and business partners with whom she later organized a free seminar for local small companies. In this example the main goal of sharing is to share skills, equipment, and so on for the organization of this event, as well as to create a platform for the development of new networks.

\section{LEISURE TIME}

Analysis of online discussions showed that neighbors play board games, go to the movies, travel, run together, organize beauty workshops, and so on. While many of these gatherings are spontaneous, some initiatives happen regularly. For several months in 2017, a local trainer conducted fitness training with baby strollers for young parents. Informant INT11 organized in WhatsApp a group chat for Kudrovo mothers, in which participants provided support for each other-from giving advice 
to borrowing money-and arranged various events. Missing her meetings with Saint Petersburg friends after she moved to Kudrovo, informant INT05 organized Mafia games: she created a VK page to recruit participants to play in her studio apartment. A professional trainer (INT07), unhappy with poor interactions among children on the playground and noninvolvement of parents, led weekly outdoor learning games, which combined physical training and psychological development. These are only some examples of free activities that residents launched for their neighbors.

Many of these initiatives ended or transformed into commercial projects. For instance, informant INT01 had started by organizing free yoga practices in the parks and later, together with her colleagues, opened a yoga studio in Kudrovo. At the same time, new initiatives appear every year. In 2019 a new mothers club started in Kudrovo. Mothers share their experience with each other, providing free courses and master classes on foreign languages, debates, art, theater, sports, dance, ecology, makeup, cooking, first aid, time management, knitting, and other subjects. Mothers may attend these meetings with their children. The initiative is aimed not only at physical, intellectual, and professional development but also at building a community of local mothers. Other activities organized by Kudrovo neighbors include book clubs, barbecues, and free dances. Some residents create collective holiday celebrations by, for example, putting New Year trees in common areas of their buildings.

These initiatives have their own VK pages and chats or at least some online presence. To be published on $\mathrm{KL}$, a post needs the approval of the administrator that is not always easy to get. Several informants told me that, even though they wanted to publicize free events, the administrator asked them to pay for their postings. In such cases, many opted to create their own VK pages. Others launched their own channels for other purposes: to consolidate all information in one place and have better control over it. Informant INT09 was unhappy about the abundance of negative information on $\mathrm{KL}$, where participants complained about all kinds of problems and argued with each other, so he started his VK page to report on cultural events.

However, the majority of $\mathrm{KL}$ posts are not to publicize activities organized by Kudrovo residents. Participants ask their neighbors for advice-legal, medical, culinary, marital. They exchange information about where to take shoes for repair or order the best pizza. They share their emotions, from disappointment by the postponement of the opening of Kudrovo metro station to their fascination with the beauty of local sunsets. They complain about a neighbor who flicked cigarettes from the balcony, and they express gratitude to another neighbor who gave money when they lost their credit card. KL is also a platform that helps residents to formulate rules of living together: coexistence both offline (whether it is ok to engage in noisy activities like drilling during children's nap time) and online (whether the publication of anonymous posts should be prohibited). Polls, a built-in VK instrument, are often used to collect opinions on various matters.

All VK pages have restrictions of a maximum of 50 posts per day. As KL participants usually submit more posts for publication every day, several ways are used to bypass this limitation. One is to put several announcements on a similar topic (e.g., lost and found) in one post. As the neighbors' insatiable desire to communicate often 
leads to off-topic comments, the KL administrator found another interesting solution: posts titled "Morning Chat" and "Night Chat" are published every morning and evening, respectively. In these posts, conversations are not shaped by any particular topic, and the comments are visible to everyone; they are a kind of online sidewalk, a place where neighbors joke, quarrel, ask for advice, or wish each other a good day.

\section{LOCAL IDENTITY}

In 2016 the private internet radio station Gorod Kudrovo (Kudrovo Town) announced on its VK page a competition for lyrics to the folk hymn of Kudrovo. Residents submitted their verses, and the town's unofficial hymn was composed of several of them and recorded by professional musicians. Besides the participatory composition of this song, the verses themselves attest to neighborliness:

Here they will always help you

They will give you advice and a ride to the metro station

And they will tell you what and where to buy

How cool living in Kudrovo is!

KL participants have also composed the "March of Kudrovo," couplets, and a rap song with the refrain "Kudrovo is my town, I'm glad that I live here." Many posts contain poems, and several participants have come to be recognized on KL as local poets. Some of these verses are enthusiastic, focused on the hospitality of people and particular landmarks of the town, while others are satirical, to attract attention to long-standing problems and ridicule local authorities.

Both cooperativeness and infrastructural failures are significant for local identity; for example, traffic jams are not only a nuisance for the residents but also a driver of collective actions by activists and an inspiration for creative locals to produce jokes and artworks. Traffic jams, Sosnowsky's hogweed, vkusniashka, and cheloveinik ("human anthill," an area with high-rises) are common symbols for many new developments, so participants keep searching for what is distinct about Kudrovo. Some local symbols are well-known to KL participants but cannot be easily read by outsiders: a hypnodom (a building with hypnotic facade design), a private toll road leading out of Kudrovo to the highway, a traffic control barrier with height restriction where trucks regularly get stuck, or a purple morozhenka (the diminutive for "ice cream"). The last "attraction" is an ice cream cone, of strange color and with a face, painted on the local ice cream stand. KL participants criticized the stand for the illfavored design and unauthorized trade. The local activists suggested that residents complain to the authorities, and eventually the ice cream stand was uninstalled. The purple morozhenka, came to symbolize several key issues of local identity: the activism of residents and their frustration with authorities, fight against illegal business, and the residents' wish to have a well-designed and esthetically homogeneous environment. This purple ice cream became an object of jokes and caricatures and appeared on KL in several versions of the town's potential coat of arms and as a handmade brooch. 
Another example of identity construction is a humorous KL post that suggested compiling a dictionary of the "local language." The comments generated many terms that referenced sharing practices, soundscapes of neighborness, infrastructural weaknesses, and neologisms formed from activists' and officials' surnames.

A Kudrovo artist creates comic pictures that are published in the KL photo album "Kudrovo Is...." The drawings express criticism towards developers and officials, as well as self-irony about the ingenuity of Kudrovo residents, their shyness to speak offline and overuse of online communication, amusing collisions and conflicting habits of neighbors (e.g., having sex in apartments with acoustically transparent walls). The artist is inspired by the most outrageous incidents, touching initiatives, bizarre online posts, and, therefore, her art is the "annals" of Kudrovo neighborness and an ever-growing directory of local heroes and antiheroes.

The local identity of Kudrovo residents is shaped in multiple ways. Sometimes it is defined in the opposition to Nevskii district of Saint Petersburg, to other parts of Vsevolozhskii district of L0, other new developments bordering the city, and so on. In other discussions, it is created around a few local landmarks (e.g., Gustav Klimt's artworks painted on Kudrovo facades; see Figure 1).

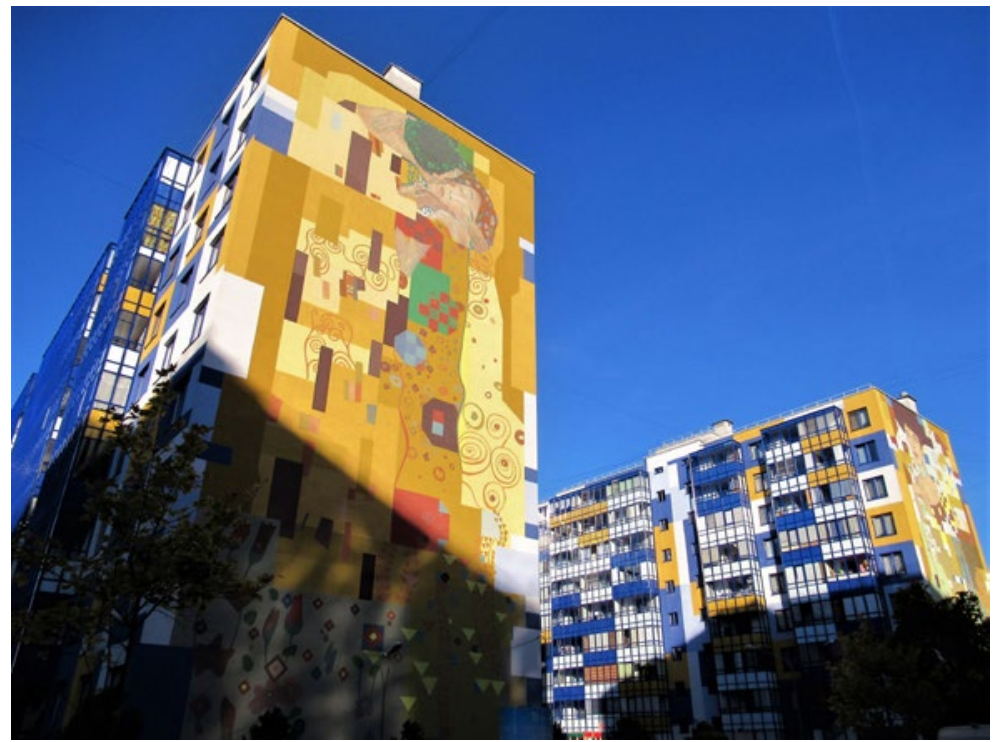

Figure 1. Vienna housing complex in South Kudrovo ${ }^{25}$

According to a KL poll, to which 1,127 participants responded, for 39 percent of them the exterior design of apartment buildings played a role in the decision to move to Kudrovo, 34 percent were indifferent to the designs, and 27 percent were undecided. For some, the decision to move to Kudrovo was shaped by the price and location of the housing, as well as closeness to the IKEA/Mega shopping mall. Other

${ }^{25}$ All photos are by author. 
participants said that they had been depressed after visiting the monotonic highrises of Parnas and Murino but fell in love with Kudrovo, whose colorful buildings put a smile on their faces. The KL newsfeed is full of photos and videos with views of Kudrovo from all sides and heights, in different seasons and times of day, and with comments lost in admiration.

No data on migration to and from Kudrovo is available; however, the movement in both directions is visible: some residents leave Kudrovo being exhausted by traffic jams and disorder, while others move to Kudrovo being attracted by close-knit groups of activists and vibrant social media. But even those who have relocated far away from Kudrovo often stay in contact and continue to participate in the exchange economy with their former neighbors.

A satirical KL post sought to formulate the distinctive qualities and draw a portrait of an average Kudrovo resident. According to the post's author, Kudrovo inhabitants walk from Vienna to London daily (see Figures 1 and 2) but can hardly make it to Saint Petersburg. They save animals but cannot stand dog poop on sidewalks or unmuzzled pets. They hate their managing company but contact it with any minor mishap. They take revenge on neighbors' automobiles blocking the exit but park their own cars even worse. Whether such definition shows conflicting values of different groups or double standards within the same person, at first glance it seems difficult to find common features. However, the post's author specified that typical Kudrovo residents are voiceless offline but very loud online, are generous and share everything with their neighbors, deal daily with infrastructural failures, and are multifaceted individuals who develop and grow every day. This post demonstrates the need to create a unity among this diverse crowd and shows that each participant contributes to the construction of the collective identity of Kudrovo residents.

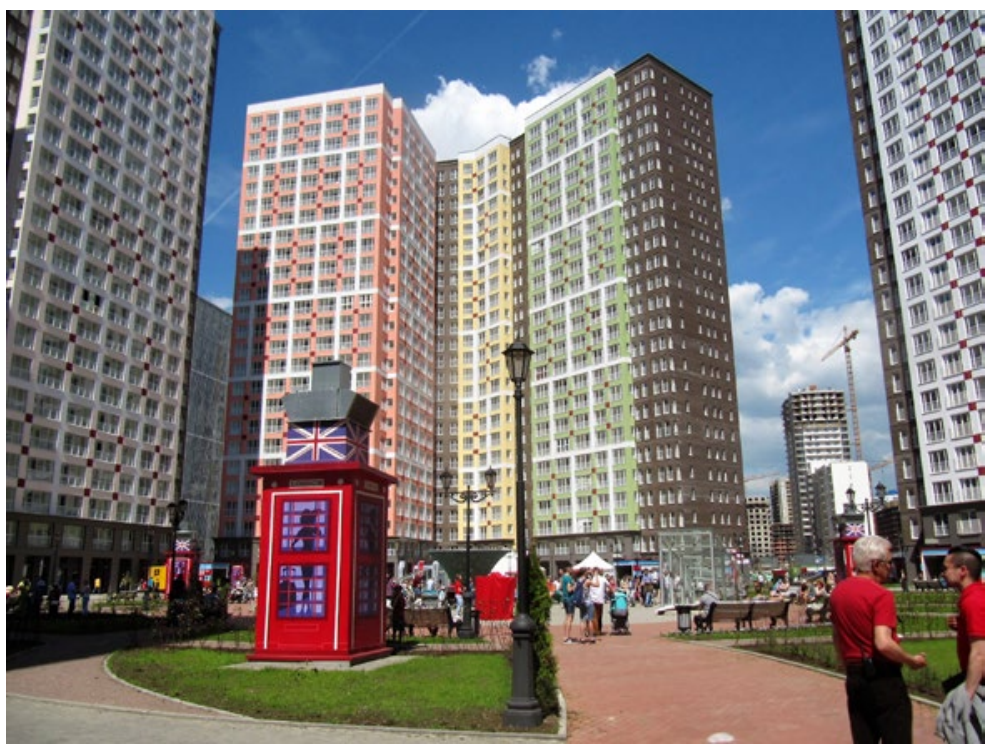

Figure 2. London housing complex in South Kudrovo 
As I have discussed above, the town's problems and frustrations of residents are as important for identity production as their strengths and achievements. Multiple comic pictures, hashtags, poems, and jokes turn various tensions and discomforts, such as lack of parking lots or the all-the-colors-of-the-rainbow water from the tap, into local specificities and reformulate the self-ironic qualities of residents (e.g., being a naïve mortgagor who believed in deceitful promises of developers) into a significant part of local identity. Such self-description and reinterpretation of current nuisance into distinctive characteristics of the territory and its inhabitants may also help to overcome the challenges (Brednikova and Zaporozhets 2016). A study of internet forums' discussions on migration to a suburban district near Irkutsk (Grigorichev 2013) demonstrated how new residents reclaimed and customized the territory by the means of facetious naming and constructing new reference points (e.g., adding internet forum participants' addresses and future infrastructure on the mental map of the district), instead of obeying the existing geographical names and landmarks. Although most struggles and everyday practices of Kudrovo residents are similar to those of inhabitants of other new developments in Saint Petersburg and other cities, their identity is rooted in this particular locality rather than is shaped by being a high-rise dweller.

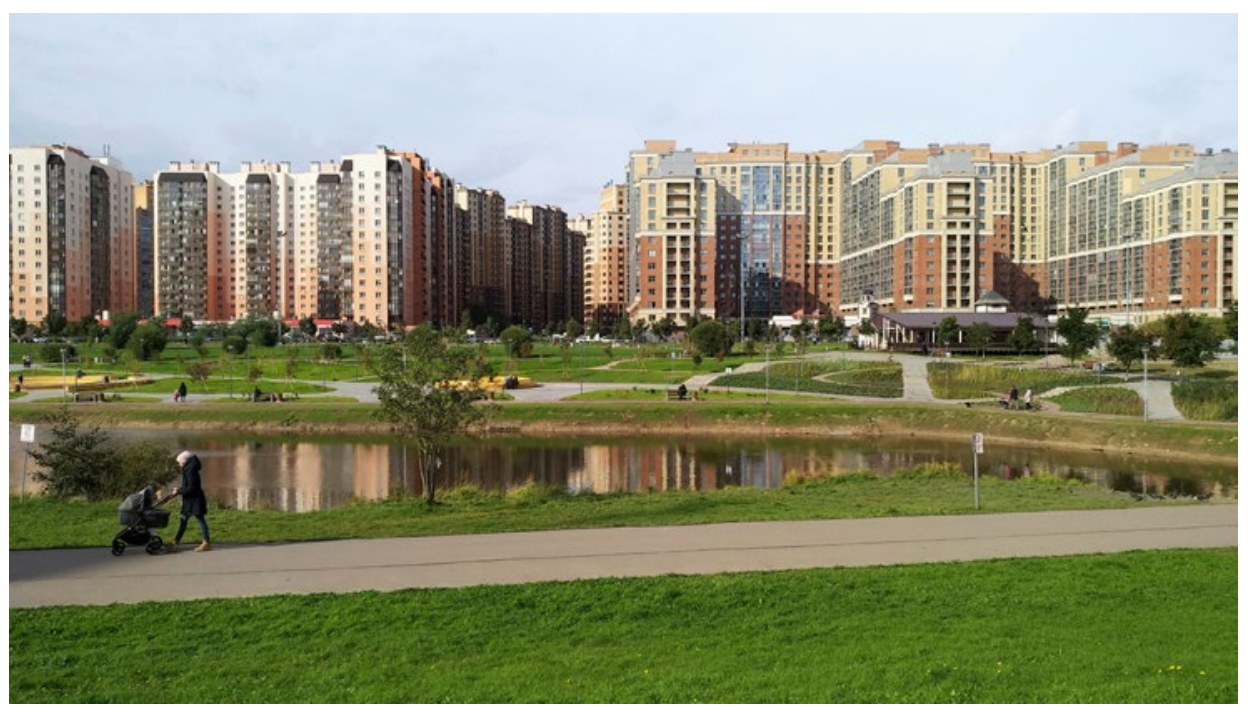

Figure 3. View of North Kudrovo from Novyi Okkervil' Park

Another widely discussed topic on $\mathrm{KL}$ is the identification of residents within Kudrovo. The Novyi Okkervil' district (Figure 3), or North Kudrovo, and South Kudrovo sometimes compete for resources and their management: where to locate a new post office, which town exits to expand, and so on. These fights that often take place online, sarcastically called "the civil war between the North and the South of the United States of Kudrovo," divide people into the northerners (local "elite") and southerners who, according to the (self-)ironic comments, are poor people living in the crime- 
prone area. Although minor differences can be detected (e.g., because some buildings in North Kudrovo are gated communities, their inhabitants might have to deal with drugs stashing less frequently), this distinction seems insignificant and imaginary. However, it demonstrates that Kudrovo residents are thirsting to construct various types of local identity, broader and narrower ones, that can be used for neighbors' cooperation or competition among various initiatives depending on the particular circumstances.

\section{DISCUSSION}

As was demonstrated above, SNSs are part and parcel of neighborness in Kudrovo. Many initiatives start online with monitoring the interest of neighbors, planning, and recruiting participants. Then the interactions of neighbors migrate to the streets of Kudrovo, but later the offline activities reappear online in photos, posts, and reports. Even those activities that were intended to take place only offline can often be found online as well: for example, a resident's request asking neighbors to decrease the sound of their sexual intercourse originally posted in the building was reposted on KL by another resident.

SNSs are not simply an instrument that helps residents broadcast their offline activity and not just a channel to attract more participants, to ease and speed up neighbors' interactions. Most initiatives mentioned above would not happen if these groups and chats did not exist, and not only because informants would not knock on the neighbors' doors or because reaching thousands of residents would be difficult. Without SNSs this type of relationships with neighbors-these motives, practices, and feeling of belonging, when anyone can appeal to this depersonalized hybrid neighborness for any kind of help and any sort of advice as if it was not a town of strangers but a close circle of trust-would not be born at all.

However, SNSs not only enable these initiatives but also restrict them in many ways. VK groups themselves are hybrids because they are digital platforms managed by humans. The barriers are constantly installed and uninstalled and transformed by various actors-VK managers, administrators of VK pages, participants changing the pages' rules-as well as by digital infrastructure itself. Participants and administrators are also constantly in search of ways to circumvent the restrictions. Both the possibilities of these digital platforms and their barriers stimulate residents to launch channels, groups, and pages for their initiatives. Therefore, digital platforms coproduce hybrid neighborness, and Kudrovo residents help platforms to proliferate by creating hundreds of local VK pages, recruiting new people to WhatsApp, and so on. Platforms not only develop in size but get new features, learn new skills, and adapt to the needs of participants. Participants also are hybrids of humans and their digital alter egos, because not only do they act differently in offline and online communications, as my informants reported, but they may have several online profiles, including fake ones.

Some Kudrovo residents do not use or are less visible on SNSs (e.g., elderly people and migrants, in the opinion of informants). They may have "old-school" relation- 
ships with neighbors: communicate face-to-face with people living nearby. However, they are not entirely excluded from hybrid neighborness: their activities (decorating the hallway, planting flowers in the common garden) are documented on KL by others and inspire neighbors to do the same. Although they are not directly and consciously involved in hybrid neighborness, they still influence and are influenced by it (for example, they, as occasional passersby, may join offline activities that were born online).

Hybrid neighborness is fluid. Although this neighborness is rooted in Kudrovo, its geographical boundaries are moving: like a rip tide, it can pull people in from the neighboring districts; or like a wave, it can throw Kudrovo residents far away, but they still will be engaged in it. Some participants leave it for good, new participants come and join it, but hybrid neighborness stays alive. Does it mean that every geographical unit or vernacular district where citizens are actively involved in online communication automatically becomes hybrid neighborness? What is the minimal and maximal size of the area for which it makes sense to talk about hybrid neighborness? Both are empirical questions that can be answered by studying a particular territory and relationships of its residents. In the heart of this Kudrovo hybrid neighborness is the town, but in other cases it can be a district, a neighborhood block, or even one apartment building.

Hybrid neighborness allows newcomers to read all stories of previous conflicts and victories, to understand local symbols and words in the Kudrovo vocabulary. A newcomer does not need to cultivate relationships with gatekeepers to be introduced to other neighbors or meet them one by one. Simply by exploring Kudrovo online resources, a new resident quickly gets the necessary competence and directly addresses all participants. It does not mean that all barriers fall: for instance, it is easier to get your post published if you have a good relationship with the VK page administrator. However, most informants perceived these barriers in online communication with neighbors as lower than in offline contacts. The capabilities provided by the digital infrastructure and an easy switch between different modes of interaction allowed even those of my informants who previously refrained from communication with neighbors to feel safer and motivated them to build networks. This finetuning of interactions (I call it "manageability") to reach the desired level of intensity, intimacy, risk, comfort, and so on is an essential feature of hybrid neighborness.

The volume of data on VK is large, but keyword search allows to get the required information efficiently. Hyperlinks leading to previous posts, personal pages, and other online channels unite them all into a huge database that participants address to find a wide spectrum of resources. The deletion of pages and their content in VK is a time-consuming process. That is why most posts and comments, as well as abandoned pages, are still visible online after many years, and it makes them a great source of information for both neighbors and researchers.

Inside hybrid neighborness, a large network of Kudrovo residents and localized digital infrastructure, multiple smaller networks flash and fade. Each of these small networks (initiatives) is a collaboration of various actors - for instance, authorities, 
developers, roads, plants, animals, and tools-but all of them include Kudrovo residents and social media. Some of these initiatives were started by nonhuman actors (e.g., electric wire), while others were launched by residents who, similar to the overheated wire, felt some unease, dissatisfaction, loneliness, or, on the contrary, a stroke of insight, enthusiasm, and excess of energy. But usually, it was a post on KL or message in WhatsApp that made these interactions the cases of neighborness. All participants of hybrid neighborness are the power put on hold and waiting to be activated. When any element of hybrid neighborness advances into action and connects with other participants through these digital media, a new initiative may appear if enough participants join it. It is a kind of Russian doll: within all-Kudrovo hybrid neighborness, there are many networks, which can be focused on a particular issue, inside each of them may be few smaller networks of different types. Even though many aforementioned initiatives were terminated after some time, new ones came to replace them. A large number of all these networks of different sizes and levels is what allows hybrid neighborness to stay alive.

Latour (2005) wrote that there are no groups per se but the process of group formation, and we can see groups only in their activity. According to him, the continual appearance and disappearance of groups is the default, while the cases of their stability are something unique and worth studying. The stability of hybrid neighborness in the case of Kudrovo is provided by such strong elements as certain VK pages, group administrators, and local activists, which work daily to maintain these connections among residents, digital infrastructure, and other actors. In particular, the role of $\mathrm{KL}$ and its satellite pages is important in producing this hybrid neighborness. There are hundreds of Kudrovo VK pages, but not many of them actively engage residents and create this feeling of belonging. Some of them are primarily aimed at advertising; in some of them the administrators are the only ones who write posts; in others, the postings happen infrequently. Unlike other administrators who create uniform VK pages for each district of Saint Petersburg or L0, the KL administrator lives in Kudrovo and is personally involved in neighbors' activities. KL represents a balanced platform, in which main voices are given to residents, advertising is restricted to a maximum of three posts per day, and the administrator steps in quickly when necessary.

The kaleidoscope of the initiatives listed above brings us closer to the understanding of the relationships that Kudrovo residents want to have with their neighbors. The analysis of these activities also puts all failures of public and private bodies in the spotlight, demonstrates holes in the social, cultural, and transport infrastructure, which participants repair, and shows their needs that are not addressed by any organizations. Neighbors' initiatives are often criticized for canalizing the protest potential of residents into small acts of beautification. However, the study illustrates that hybrid neighborness may produce not only DIY but various types of initiatives including political ones, and the proportion of various kinds of activities depends on a combination of particular actors engaged in the network. 


\section{REFERENCES}

Brednikova, Olga, and Oksana Zaporozhets. 2016. “Veter, ustalost' i romantika nochi (ob osobennostiakh novykh zhilykh massivov)." Laboratorium: Russian Review of Social Research 8(2):103-119.

Chernysheva, Liubov. 2019. "Rossiiskoe getto: Voobrazhaemaia marginal'nost' novykh zhilykh raionov." Goroskie issledovaniia i praktiki 4(2):37-58. https://doi.org/10.17323/usp42202037-58.

Chernysheva, Liubov. 2020. "Onlain i offlain konflikty vokrug gorodskoi sovmestnosti: Zabota o gorodskom prostranstve na territorii bol'shogo zhilogo kompleksa." Zhurnal sotsiologii $i$ sotsial'noi antropologii 23(2):36-66. https://doi.org/10.31119/jssa.2020.23.2.2.

Chernysheva, Liubov, and Elvira Gizatullina. 2021. "VKontakte's sosediami: Cherty i praktiki gibridnogo sosedstvovaniia v bol'shom zhilom komplekse Sankt-Peterburga." Laboratorium: Russian Review of Social Research 13(2):39-71. https://doi.org/10.25285/2078-1938-2021-13-2-39-71.

Grigorichev, Konstantin V. 2013. "'Virtual'nyi' prigorod: Konstruirovanie soobshchestva v internetforumakh." Izvestiia Irkutskogo gosudarstvennogo universiteta (seriia "Politologiia. Religiovedenie") 2:270-281.

Hamari, Juho, Mimmi Sjöklint, and Antti Ukkonen. 2016. “The Sharing Economy: Why People Participate in Collaborative Consumption." Journal of the Association for Information Science and Technology 67(9):2047-2059. https://doi.org/10.1002/asi.23552.

Hampton, Keith, and Barry Wellman. 2003. "Neighboring in Netville: How the Internet Supports Community and Social Capital in a Wired Suburb." City \& Community 2(4):277-311. https:// doi.org/10.1046/j.1535-6841.2003.00057.x.

Harris, Kevin, and Hugh Flouch. 2010. "Online Neighbourhood Networks Study: Social Capital and Cohesion." The Networked Neighbourhoods Group. https://www.londoncouncils.gov.uk /node/27009.

Kovács, Borbála, Jeremy Morris, Abel Polese, and Drini Imami. 2017. "Looking at the 'Sharing' Economies Concept through the Prism of Informality." Cambridge Journal of Regions, Economy and Society 10(2):365-378. https://doi.org/10.1093/cjres/rsw046.

Latour, Bruno. 1992. "Where Are the Missing Masses? The Sociology of a Few Mundane Artifacts." Pp. 225-228 in Shaping Technology/Building Society: Studies in Sociotechnical Change, ed. by Wiebe E. Bijker and John Law. Cambridge, MA: MIT Press.

Latour, Bruno. 2000. "When Things Strike Back: A Possible Contribution of 'Science Studies' to the Social Sciences." British Journal of Sociology 51(1):107-123. https://doi .org/10.1111/j.1468-4446.2000.00107.x.

Latour, Bruno. 2005. Reassembling the Social: An Introduction to Actor-Network-Theory. New York: Oxford University Press.

Matei, Sorin, and Sandra J. Ball-Rokeach. 2001. "Real and Virtual Social Ties: Connections in the Everyday Lives of Seven Ethnic Neighborhoods." American Behavioral Scientist 45(3):550564. https://doi.org/10.1177/0002764201045003012.

Miller, Daniel, Jolynna Sinanan, Xinyuan Wang, Tom McDonald, Nell Haynes, Elisabetta Costa, Juliano Spyer, Shriram Venkatraman, and Razvan Nicolescu. 2016. How the World Changed Social Media. London: UCL Press.

Miller, Daniel, and Don Slater. 2000. The Internet: An Ethnographic Approach. 0xford: Berg.

Niederer, Sabine, and Ruurd Priester. 2016. "Smart Citizens: Exploring the Tools of the Urban Bottom-Up Movement." Computer Supported Cooperative Work (CSCW) 25(2-3):137-152. https:// doi.org/10.1007/s10606-016-9249-6.

Rheingold, Howard. 2000. The Virtual Community: Homesteading on the Electronic Frontier. Rev. ed. Cambridge, MA: MIT Press.

Souza e Silva, Adriana de. 2006. “From Cyber to Hybrid: Mobile Technologies as Interfaces of Hybrid Spaces." Space and Culture 9(3):261-278. https://doi.org/10.1177\%2F1206331206289022.

Talen, Emily. 2019. "DIY Neighborhoods." Pp. 99-112 in The Palgrave Handbook of Bottom-Up Urbanism, ed. by Mahyar Arefi and Conrad Kickert. New York: Palgrave Macmillan. 
Tykanova, Elena V., and Ksenia A. Tenisheva. 2020. “V plenu 'effekta sosedstva': Sotsial'nyi kapital i aktivizm v novykh anklavnykh zhilishchnykh kompleksakh." Zhurnal sotsiologii i sotsial'noi antropologii 23(2):7-35. https://doi.org/10.31119/jssa.2020.23.2.1.

Volont, Louis. 2019. "DIY Urbanism and the Lens of the Commons: Observations from Spain." City \& Community 18(1):257-279. https://doi.org/10.1111/cico.12361.

Voskresenskiy, Vadim, Ilya Musabirov, and Daniel Alexandrov. 2016. "Private and Public Online Groups in Apartment Buildings of St. Petersburg." Pp. 301-306 in WebSci '16: Proceedings of the 8th ACM Conference on Web Science. New York: Association for Computing Machinery.

Zaporozhets Oksana N., and Ekaterina G. Lapina-Kratasyuk. 2015. "Antropologiia tsifrovogo goroda: K voprosu o vybore metoda." Etnograficheskoe obozrenie 4:41-54.

Zhelnina, Anna A., and Elena V. Tykanova. 2019. "Formal'nye i neformal'nye grazhdanskie infrastruktury: Sovremennye issledovaniia gorodkogo local'nogo aktivizma v Rossii." Zhurnal sotsiologii i sotsial'noi antropologii 22(1):162-192. https://doi.org/10.31119/jssa.2019.22.1.8.

\section{LIST OF INTERVIEWEES}

INT01 -female, 31 years old, divorced, no children, university degree, teacher

INT02_female, 27 years old, married, no children, university degree, self-employed

INT03-female, 28 years old, married, no children, university degree, marketing specialist

INT04-female, 34 years old, married, two children, university degree, housewife

INT05-female, 37 years old, married, two children, secondary education, self-employed

INT06 - female, 28 years old, married, no children, university degree, engineer

INT07-female, 31 years old, married, two children, university degree, housewife

INT09-male, 30 years old, married, no children, university degree, manager

INT10 - female, 38 years old, married, one child, university degree, housewife

INT11 - female, 31 years old, married, two children, university degree, housewife

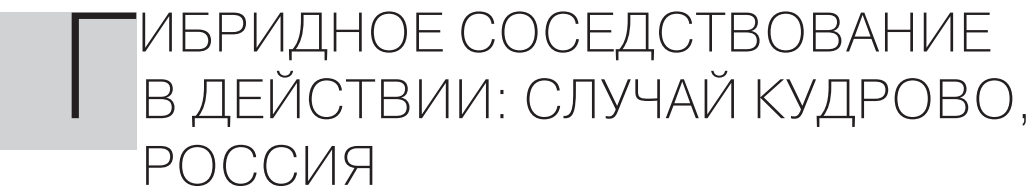

\section{Ольга Громашева}

Ольга Громашева, факультет социальных наук, Вагенингенский университет (Нидерланды). Адрес для переписки: Rural Sociology group (Bode 50), PO Box 8130,6700 EW Wageningen, Netherlands.olga.gromasheva@gmail.com.

Статья основана на результатах серии исследований автора, проводимых в городе Кудрово Ленинградской области с 2017 года, которые осуществлялись в рамках двух коллективных проектов: «Новые городские экономики участия: $p 2 p /$ sharing и цифровая экономика» при финансовой поддержке Леонтьевского центра и «Слоеный пирог соседства» при финансовой поддержке Фонда Коне.

В работе анализируются соседские отношения в новостройках Кудрово - города в Ленинградской области, расположенного на границе с Санкт-Петербургом. Кудрово является ярким примером соседства, большая часть которого завязывается и протекает онлайн, но не остается сугубо в цифровом пространстве, а выплескивается 
на улицы города, производя многочисленные офлайн-инициативы и меняя материальность среды. В Кудрово я задокументировала множество соседских инициатив, ориентированных на повышение безопасности, развитие территории, практики альтернативной экономики, формирование местной идентичности, досуговые, образовательные, культурные и прочие активности. Статья вдохновлена акторносетевой теорией и уделяет внимание различным человеческим и нечеловеческим акторам, а основной акцент сделан на роли местных жителей и цифровой инфраструктуры в этих взаимодействиях. Примечательно, что в анализируемых практиках контакты лицом к лицу или проживание в одном доме - не то, что позволяет жителям максимально реализовать потенциал соседских отношений. Гораздо важнее становится подключенность к телу «гибридного соседствования» как к человеческо-цифровой сети, которая функционирует круглосуточно, объединяет десятки тысяч жителей, сохраняет историю всех предыдущих взаимодействий, мгновенно откликается и позволяет участникам обращаться за помощью в широком диапазоне ситуаций от получения моральной поддержки до решения практических вопросов. Некоторые примеры складывающихся сетей, а также существующих ограничений и стратегий их преодоления приведены в статье, однако основная цель представленной работы - показать особенности и потенциал гибридного соседствования на примере того, как оно работает в Кудрово.

Ключевые слова: гибридизация; соседство; новостройки; человеческие и нечеловеческие акторы; цифровая инфраструктура; шеринговые практики 